\title{
2008 Küresel Finansal Kriz ve Bu Krizin Türkiye'deki Ekonomik Göstergelere Etkisi
}

\section{Global Financial Crisis and the Effects of this Crisis on Economic Indicators in Turkey}

\author{
Murat Kesebir a,* \\ ${ }^{a}$ Dr., Sırrı Çelik Bulvarı, Ekşioğlu Sultanevleri, A3, D16, 34788, Taşdelen, Çekmeköy, İstanbul/Türkiye. \\ ORCID: 0000-0001-6462-6860
}

\section{MAKALE BILGIISI}

\section{Makale Geçmişi:}

Başvuru tarihi: 12 Ocak 2018

Düzeltme tarihi: 11 Mart 2018

Kabul tarihi: 29 Mart 2018

Anahtar Kelimeler:

Küresel Kriz

Ekonomik Göstergeler

Finansal Piyasalar

\section{ARTICLE INFO}

\section{Article history:}

Received 12 January 2018

Received in revised form 11 March 2018

Accepted 29 March 2018

\section{Keywords:}

Global Crisis

Economic Indicators

Financial Markets
ÖZ

Ekonomik yapı her zaman bir dengeyi oluşturur ve bu denge de ülkeler arası ilişkilere bağlıdır. Küreselleşme ile birlikte ortaya çıkan bu ilişkiler, ülkeler arası ekonomiyi etkilemekte ve çeşitli sonuçları doğurmaktadır. 2000'li yıllarla birlikte, ekonomik anlamda sınırların kalkması bir ülkede meydana gelen bir krizin bütün ülkelere yayılmasına da yol açmıştır. Bunun en iyi örneğini, 2008 yılında oluşan global krizde görmekteyiz. Amerika'da mortgage kredilerinin geri ödenmesi süreci ile başlayan problemin, ülkenin finansal yapısına etkisi ve sonrasında bu krizin dünyaya dalga dalga yayılması takip etmektedir. Çalışmamızda, bu küresel krizin öncesinde küreselleşme kavramına değinilmiş olup, sonrasında krizin belirtileri, gelişmesi ve yayılması detaylandırılmıştır. Ayrıca, Türkiye ekonomisine etkisi de; büyüme ve üretim, işsizlik ve enflasyon verileri ile açıklanmıştır. Amerika'da başlamış bir krizin bütün dünyaya yayılması ve Türkiye'nin de bu krizden ekonomik olarak nasıl etkilendiği, çalışmamızın odak noktasını oluşturmaktadır.

\section{A B S T R A C T}

Economic structure always creates a balance, and this balance depends on the relations between the countries. The relations that arise with the advent of globalization, between countries impacts the economy and pose various results. During 2000s, countries became without borders in terms of economy which led crises to spread to all countries. The best example of this might be the global crisis of 2008. The repayment process of the mortgage loans in America started the problem which influenced the financial structure of the country in the aftermath of this crisis. It is followed by the wave propagation around the world. In our study, the concept of globalization the crisis has been discussed and detailed the development and spreading of symptoms in the aftermath of the crisis. In addition, the impact of crisis on the Turkish economy, growth and production, unemployment and inflation data are described. The study's focus is the crisis that started in America and spread to the whole world and how Turkey was affected by the economic crisis.

\section{Giriş}

1929 yılında meydana gelen büyük krizin ardından dünyada belirli zamanlarda ülke bazında çeşitli krizler ortaya çıkmıştır. Fakat bu krizlerin gelişmesi ve yayılması açısından 2008 yılında meydana gelen kriz yapısal olarak diğerlerine göre farklılık göstermektedir. Şöyle ki, dünya ekonomisinin üretim artış hızına bakıldığında; 2005'te dünya ekonomisinin $\% 4,4$ oranında büyüdüğü ve bu büyümenin düşük oranda olmasının en önemli sebebinin petrol fiyatlarının artması olduğu saptanmıştır. 2006'da ekonomik büyüme hızının 0,7 puanlık bir artışla \%5,1'e yükseldiği belirtilmiştir (Yıldırım, 2010: 47). Fakat 2007 yılında ortaya çıkan mortgage krizi ile birlikte, yükseliş seyrinde devam eden dengeleri değiştirmiş ve durumu tersine çevirmiştir.

Çalışmamızın konusu olan 2008 küresel finansal krizi, 2007 yılında ABD'de başlamıştır. ABD'de düşük faiz oranları ile ev sahibi olmak isteyen düşük gelirli kişilere mortgage kredileri verilmiştir. Fakat 2004 yılı sonrasında yükselen faiz oranları ile birlikte bu yapıda bozulmalar meydana gelmiştir. Düşük gelirli kişilerin yükselen faiz ile birlikte ödeme güçlüğü ile karşılaşması, kredi krizinin büyüyerek yayılmasına ve mortgage piyasasını tamamen etkilemesine yol açmıştır. Devamında sadece mortgage ile sınırlı

* Sorumlu yazar/Corresponding author.

e-posta: muratkesebir@hotmail.com 
kalmayıp bütün ülkeye ve sonrasında dünyaya yayılan bir kriz olmuştur.

2008 yılında yaşanan bu krizin, bugüne kadar yaşanan krizlere göre en önemli farkı, az gelişmiş ve yükselen ülke ekonomileri (çevre ülkeler) yerine gelişmiş ekonomileri (merkez ülkeleri) etkilemiş olmasıdır. Gelişmiş ülke ekonomilerinin daha fazla etkilenmesinin nedeni, krizin yoğun olarak yaşandığı mortgage piyasalarının ve kredilere dayalı varlık türlerini üretecek finansal türev piyasalarına daha fazla sahip olmasıdır. Yükselen ekonomiler ise, gerçekleştirmiş oldukları reformlar ile birlikte yaşanan krizlere duyarlı bankacılık sistemine sahip olduklarından daha az etkilenmişlerdir (Akın ve Ece, 2009: 155).

2008 küresel finansal krizi yarattığ 1 etkiler sonucunda tüm dünyada talep ve büyümede daralmaya neden olmuştur. Özellikle ABD ekonomisinin daralması üzerine, dünya etkilenirken Türkiye ekonomisinde de daralmalar meydana gelmiştir. Bu çalışmada, krizin global boyutlara yayılma nedenini daha iyi anlayabilmek için küreselleşme olgusuna değinilerek, küresel mali krizin Türkiye ekonomisine etkileri değerlendirilecektir.

\section{Küreselleşme ve Yeni Gelişmeler}

1990’lı yılların başında dünyada hızlı bir küreselleşme yaşanmaya başlamıştır. Literatürde küreselleşme sürecinin oluşmasında meydana gelen unsurlar arasında iletişim ve bilişim teknolojisi alanında ortaya çıkan gelişmeler dikkati çekerken, diğer bir sebep ise göz ardı edilmiştir. Sovyetler birliğinin dağılması ile birlikte, yeni bağımsız devletlerin kuruluşu, iki kutuplu bir dünyadan tek kutuplu bir dünyaya geçişi göstermiştir (Seyidoğlu, 2003: 141).

Küreselleşme kavramının ekonomik ve siyasi alanda kullanılmaya başlanması $M$. Teacher ve R. Reagan tarafindan temsil edilen muhafazakâr anlayışın iktidara geldiği 1980'li yıllara rastlamış, 1990'lı yıllardan itibaren kavram iyice yaygınlaşmıştır. Küreselleşme kavramı ile ortaya çıkan yeniden yapılanma sürecinde ekonomik, siyasi, sosyal ve kültürel anlamda değerlerin yayılması, gelişmiş ve gelişmekte olan ülkelerde benimsenen iktisat ve sanayi politikaları ve sanayileşme türü gittikçe benzer bir yapıyı oluşturmuşlardır (Yalçınkaya vd., 2012: 4). Bu süreç ekonomik küreselleşme kavramını oluşturmuştur ve bu da uluslararası ticaretin örgütlenmesi açısından dikkati çeken batılı sermaye çevrelerinin ulaştığı zenginliğe işaret etmektedir (Aktel, 2003: 57). Küreselleşme ve ileri düzeyde finansallaşmaya yol açan tüm bu gelişmeler, sonuçları 2008 krizine dayanan bir sürecin başlangıcı olmuştur.

Küreselleşme birden fazla boyuta sahip olan bir olgudur. Küreselleşme sayesinde ABD'nin küresel egemenlik yolu açılırken, sermaye hareketlerinin serbest dolaşımı sayesinde kronikleşen ABD ve İngiltere krizinden kurtulma imkânı da doğacaktır. Üçüncü olgu ise, teknolojik yeniliklerin gerçekten de dünyayı küçük bir hale getirecek olmasıdır.

\section{2008 Dünya Finansal Krizi}

2007 yılının ikinci çeyreği ile birlikte ortaya çıkan finansal kriz ilk olarak mortgage krizi olarak görünmesine rağmen, bu borçların devamında bir likidite krizini doğurmuştur. Dünya finansal krizi ilk olarak ABD'de ortaya çıkmış olsa da sonrasındaki süreçte giderek dünyaya yayılmaya başlamış ve her ülkenin finans piyasalarına sıçramıștır. Krizin merkezde yer alan belirli ülkeler ile kısıtlı kalacağı düşünülürken, kısa sürede diğer ülkeleri de etkilemiştir (Çetinkaya, 2011: 27).

ABD'de faizlerin düşük olduğu bir dönemde kişilerin ev sahibi olması için verilen kredilerin, kişilerin kredi geçmişlerine bakılmadan verilmiş olması da bir riski üstünde taşımaktadır. Çünkü sonraki süreçte bu verilmiş olan kredilerin birden yükselen faiz ile birlikte ödenmesi zorlaşmış ve çoğu insan ödeyememiştir. Sistematik olarak ilerleyen bu sürecin konut kredisi piyasalarının diğer bölümlerine de etkide bulunmaya başlamış ve finansal piyasaları tehdit eder hale gelmiştir. Piyasalarda oluşan bu güven kaybı ile birlikte finans kuruluşları pozisyonlarını kapatmaya başlamış ve nakde dönmeleri ile birlikte kredi anlamında sert bir sürecin başlangıcı olmuştur. Eylül ayına gelindiği zaman, ABD'nin yatırım bankalarından Lehman Brothers'ın iflas başvurusunda bulunması finansal açıdan sarsıntının iyice derinleşmesine ve birçok kuruluşun da bu duruma gelebileceğini göstermiştir. Bununla birlikte finansal piyasalarda birbirlerine borç verme anlamında isteksizlik meydana gelmiş ve daha yüksek risk primi talep edilmeye başlamıştır. Menkul kıymet ihracında ve özel sektör tahvil piyasasında sıkıntılar oluşmuştur. Böylece durum ilerleyen süreçte mortgage krizinden likidite krizine doğru dönüşmüş ve adım adım ilerlemiştir (Uğur, 2007: 22).

Sistematik olarak başlayan bu krizin dalga dalga ilerleyen bir seyri bulunmaktadır. Aşağıda krizin başlangıç evresinden itibaren sonuna kadarki süreç tablo olarak yer almaktadır.

Tablo 1. Küresel Finansal Krizin Kronolojik Seyri (Şubat 2007Ocak 2009)

\begin{tabular}{|c|c|c|}
\hline Dönem & $\begin{array}{l}\text { Betimleyici } \\
\text { Özellikler }\end{array}$ & $\begin{array}{c}\text { Kilit Önem Taşıyan } \\
\text { Başarısızlıkların } \\
\text { Aktörleri }\end{array}$ \\
\hline $\begin{array}{l}\text { Şubat 2007- } \\
\text { Mayıs } 2007\end{array}$ & Panik öncesi evre. & HSBC, New Century. \\
\hline $\begin{array}{l}\text { Haziran 2007- } \\
\text { Temmuz } 2007\end{array}$ & $\begin{array}{l}\text { Panik başlangıc1 } \\
\text { (tetiği çeken: Bear } \\
\text { Stearns) }\end{array}$ & $\begin{array}{l}\text { Bear Stearns, Amerikan } \\
\text { Home, West LB. }\end{array}$ \\
\hline $\begin{array}{l}\text { Ağustos 2007- } \\
\text { Eylül } 2007\end{array}$ & 2007 Paniği. & $\begin{array}{l}\text { BNP Paribas, Goldman, } \\
\text { Countrywide Financial, } \\
\text { Sachsen LB, Lehman, } \\
\text { HSBC, Basic Yelds. }\end{array}$ \\
\hline $\begin{array}{l}\text { Ekim 2007- } \\
\text { Aralık } 2007\end{array}$ & $\begin{array}{l}\text { Finansal kesimde } \\
\text { ciddi zararların } \\
\text { belirmesi. }\end{array}$ & $\begin{array}{l}\text { Merrill Lynch, Morgan } \\
\text { Stanley, Citigroup, UBS, } \\
\text { MBIA, Bank of } \\
\text { America. }\end{array}$ \\
\hline $\begin{array}{l}\text { Ocak 2008-Mart } \\
2008\end{array}$ & $\begin{array}{l}\text { Zararların artma } \\
\text { eğilimi ve Bear } \\
\text { Stearns'in nihai } \\
\text { çöküşü. }\end{array}$ & $\begin{array}{l}\text { Citigroup, Merrill } \\
\text { Lynch, UBS, HSBC, } \\
\text { Peloton Capital, Carlyle } \\
\text { Fund. }\end{array}$ \\
\hline $\begin{array}{l}\text { Nisan 2008- } \\
\text { Mayıs } 2008\end{array}$ & Zararlar hala artiyor. & $\begin{array}{l}\text { UBS, Deutsche Bank, } \\
\text { MBIA, Washington } \\
\text { Mutual, Wachovia, } \\
\text { Citigroup. }\end{array}$ \\
\hline $\begin{array}{l}\text { Haziran 2008- } \\
\text { Temmuz } \\
\text { 2008'in ortalar1 }\end{array}$ & $\begin{array}{l}\text { Kaygılar sürüyor, } \\
\text { finansal varlıkların } \\
\text { erimesinde ikinci (ve } \\
\text { daha üst) aşama. }\end{array}$ & $\begin{array}{l}\text { UBS, Morgan Stanley, } \\
\text { Merill Lynch, Lehman, } \\
\text { Bradford\&Bingley, } \\
\text { MBIA. }\end{array}$ \\
\hline $\begin{array}{l}\text { Temmuz } \\
\text { 2008'in ikinci } \\
\text { yarıs1-Ağustos } \\
2008\end{array}$ & $\begin{array}{l}\text { İkinci paniğin } \\
\text { başlangıcı (Tetiği } \\
\text { çekenler: } \\
\text { Fannie,Freddie, } \\
\text { Lehman). }\end{array}$ & $\begin{array}{l}\text { IndyMac, Barclays, } \\
\text { HBOS, National } \\
\text { Australia Bank, Merrill } \\
\text { Lynch, Fannie Mae, } \\
\text { Freddie Mac, Lehman. }\end{array}$ \\
\hline
\end{tabular}




\begin{tabular}{|c|c|c|}
\hline Eylül 2008 & $\begin{array}{l}2008 \text { Paniği: Kriz } \\
\text { Avrupa'ya da } \\
\text { yerleşiyor. }\end{array}$ & $\begin{array}{l}\text { Lehman, Merrill Lynch, } \\
\text { AIG, Lloyds, HBOS, } \\
\text { Washington Mutual. }\end{array}$ \\
\hline Ekim 2008 & $\begin{array}{l}\text { Hükümetlerin kriz } \\
\text { önleme amaçlı yoğun } \\
\text { müdahaleleri. }\end{array}$ & $\begin{array}{l}\text { Bir üsttekilere ek olarak } \\
\text { Glitnir Bank, Fortis, } \\
\text { Hypo Real, RBS, } \\
\text { HBOS, Llyods, } \\
\text { Wachovia. }\end{array}$ \\
\hline $\begin{array}{l}\text { Kasim 2008- } \\
\text { Aralık } 2008\end{array}$ & $\begin{array}{l}\text { Panikten sonraki } \\
\text { dördüncü çeyreğin } \\
\text { son iki ayı. Kriz } \\
\text { tümüyle } \\
\text { küreselleşmiş } \\
\text { durumda. }\end{array}$ & $\begin{array}{l}\text { Wells, Franklin Bank, } \\
\text { Citigroup, GMAC, } \\
\text { Downey Financial, } \\
\text { Glitnir, AIG, Goldman, } \\
\text { UBS. }\end{array}$ \\
\hline Ocak 2009 & $\begin{array}{l}\text { Finansal varlıkların } \\
\text { erimesi sürüyor. }\end{array}$ & $\begin{array}{l}\text { RBS, Deutsche Bank, } \\
\text { Mitsubishi UFJ, JP } \\
\text { Morgan, } \\
\text { Marshall\&llsley, Anglo- } \\
\text { Irish Bank, PNC, Black } \\
\text { Rock, RBC, Scotiabank, } \\
\text { RAB Capital. }\end{array}$ \\
\hline
\end{tabular}

Kaynak: Bağımsız Sosyal Bilimciler (2009)

Tablodan da anlaşılacağı üzere 2007 yılında başlayan ve kilit önem taşıyan bazı hususların etkilemesi ile birlikte 2008 yılına doğru kriz iyece ortaya çıkmış ve 2008 yılı ile birlikte ABD ile sınırlı kalmayarak birçok Avrupa ülkesinin ekonomisini de zora sokacak kadar ilerlemiştir. Krizin derinleşme belirtileri 2008 ile iyice belirginleşmiş ve seyrine devam etmiştir.

Klimek (2012) ekonomik krizin sermaye akımlarını önemli ölçüde etkilediğinin üzerinde durmaktadır. Ekonomik krizin yatırım akışlarını yeniden şekillendirdiğini belirtmekte ve ekonomik krizin dünya üzerinde büyük değişmelere neden olduğunu ifade etmektedir.

Küresel piyasalarda yaşanan bu gelişmeler ayrıca gelişmekte olan ülkelerin ekonomisini de etkilemiştir. Cari açıkları GSYH'nin \%10'undan fazla olan ülkelerde sermaye girișleri durmasıyla iç talepte durgunluk yaşanmıştır. Ocak 2008 ile Eylül 2008 arasındaki dönem incelenince, özel bankaların dışarıdan borçlanmaları düşmüştür. Şöyle ki, Kazakistan 13,2 milyar dolar, Rusya 6,6 milyar dolar, Güney Afrika'da 3,7 milyar dolar, Ukrayna 2,1 milyar dolar ve Türkiye'de 3,1 milyar dolar azalma gerçekleşmiştir. Cari fazlası olan ülkeler de dâhil olmak üzere bütün ülkeler küresel piyasalarda gerçekleşen dalgalanma ile bu krizden etkilenmişlerdir (Erdönmez, 2009: 89; World Bank, 2009: 21).

Bunun yanı sıra, Ouerghi (2013), küresel finansal kriz döviz kuru politikaları gelişmekte olan ülkelerin daha dirençli olmasına yardım etti mi sorusunu sorarak konuya yaklaşır. Çalışmada 1990'larda yaşanan kriz ile 2007-2008 yılları arasında yaşanan kriz karşılaştırılır ve önceki krizde gelişmekte olan ülkelerin finansal açıdan zayıf düşmelerine karşılık 2008'de finansal krize daha hazırlıklı ve daha güçlü hale geldiklerini ifade eder.

2008 krizine sebep olarak emtia fiyatlarında meydana gelen yükselme olarak görülse de, kredinin değil ona bağlı olarak yapılan işlemler ile birlikte oluşan bir kriz olduğu görülmektedir. Başlıca sorun ise, kredinin hızlı bir şekilde el değiştirmesidir. Türev ürünler olarak adlandırılan bu işlemler, şirketlerin diğer işlemlerden oluşan risklerini ortaya çıkaran sözleşmelerdir. Bu sözleşmelerde, geri ödememe riski oluştuğu zaman üçüncü kişilere devredilmesi yani hedge fonlara devri oluyordu. Kuruluş riski devredince, daha büyük riski üstleniyor böylece krediler ve hedge fonlar da hızlıca büyüyordu. Kuruluşlar tarafından önemli bir işlevi olan türev ürünler gittikçe yüklenmiş olunan risklerle birlikte, daha tehlikeli bir hale dönüşmüşlerdir (Gümüş ve Aydemir, 2014: 41).

2000'li yılların başında başlayıp sona doğru giderek artan likidite, bununla beraber gelen yüksek büyüme rakamları ve makroekonomik büyümeler sermaye sahipleri riskleri göz ardı etmiştir. Diğer taraftan sermaye sağlayan ve kredi veren kuruluşlar ne kadar risk olup olmadığını hesaplamadan, geri dönüşlere öngörüsüz bir şekilde yaklaşmaları finansal sektörün yara almasına yol açmıştır. FED'in yaptığ müdahalelere rağmen kriz finansal sektörde önlenememiş olup reel sektöre de yayılmıştır. Küreselleşen dünyada birbiri ile bağlantılı olan ekonomiler, krizin çok hızlı bir şekilde yayılmasına neden olmuştur (Yurdakul, 2015).

FED' in eski Başkanı Alan Greenspan krize yönelik açıklama yaparken bu yüzyılda yaşanacak kadar nadir bir olay olduğundan bahsetmiş ve Amerikan ekonomisinin durgunlaşmadan kurtulamayacağını öngörmüştür.

\section{2008 Küresel Finansal Krizin Nedenleri ve Avrupa'nın Durumu}

\subsection{Krizin Ana Sebepleri}

Ana nedenlerden biri olan likidite bolluğu Amerika'da ve Avrupa'da büyük problem yaratmıştır. Gelişmiş olan ülkelerde, özellikle ABD'de farklı fonksiyonların her birine özel mali araç ve mali kurum geliştirilmiştir. Bu mali kurum ve araçlar birbiri ile irtibatlıdır ve girift ilişskilere sahiptirler. Örnek verecek olursak, faiz haddi türev piyasaları forward swap işlemlerinden dalgalı swape kadar bir çok finansal araç sunmaktadır. Karmaşık yapılarından dolayı finansal araçları anlamak çok zordur. Sıradan yatırımcılar için her gün değişen, yenileşen ve farklılaşan finansal araçları takip etmek mümkün değildir. Özellikle anlaşılmamak istendiğinde ciddi bir saydamlı sorunu ile karşılaşılmaktadır. Saydamlıktaki bir diğer eksiklik "asimetrik bilgi" diye adlandırılan olgudur. Bu halde, bilgi yatırımcılara firmalara ve diğer aktörlere farklı hızlarla ve farklı biçimlerde ulaşmaktadır.

ABD'de 2000 ile 2006 yillarında herkesin ev sahibi olması amaçlanmış ve bu doğrultuda bankalar herkese kredi vermiştir. Bankalar verdikleri kredilere bağlı olarak riski azaltmak için menkul kıymetleştirme yolunu seçmişlerdir. $\mathrm{Bu}$ yaklaşımla riski paylaşmak hedeflenirken paylaşılan şey borç olmuştur. 2008 krizinin çıkış noktasını çoğu iktisatçı; mortgage kredisinin her gelir grubuna aynı faiz oranında ve geri ödeme planı ile verilmiş olması olarak değerlendirmez. 2008 krizinin çıkış noktası olarak, verilen kredilerin bankalar tarafindan paketlenerek tekrar tekrar satılmasi olarak görülür.

Kredileri veren kuruluşlar ise üstlerine düşen denetlemeleri yeterli şekilde yapmadıkları için ve firmaların birbirlerini tanımasından dolayı objektif kalamadıkları için kredi veren kurumlar ölçütleri ağırlaştırmış ve zamanı da kısıtlayarak sorunu daha fazla büyüterek maliyeti arttırmıştır. Bu durum hem ülke içi finansal kurumların tedbirler almasına hem de ülkeler arasındaki borçlanma koşullarının zorlaşmasına sebep olmuştur. 
Burada ayrıca üzerinde durulması gereken nokta, bankaların kredi riski ile karşı karşıya kalması ve sonrasında bunun bir likidite riskine dönüşmesidir. Bankalar bu yükümlülüklerini yerine getiremeyince ortaya çıkan bu durum, sonrasında yayılma riskini de oluşturmuş ve sadece ABD'nin değil aynı zamanda diğer ülkelerin de, kredi değerliliğinin azalmasına ve likidite sıkışıklığına yol açmasına sebep olmuştur.

\subsection{Krizinde Avrupa}

Krizin Avrupa'da hızla yayılması, ABD'nin para basarak parasının değerini düşürmesinin ardından, daha çok ihracat yapması ve Euro'ya karşı doların rekabet gücünün artması ile mümkün oldu. Bu arada, Avrupa'daki bankalar da krize girmeye başlamıştı. Hükümetlerin soruna gerekli çözümü bulamaması, piyasalara müdahaledeki gecikmeler, yetersizlikler, siyasal önceliklerle hareket etmeleri ve gerekli dirayeti gösterememeleri, üst üste geliyordu. Örneğin, İngiltere'deki Muhafazakâr Parti, seçimleri kazandıktan hemen sonra, önceden iktidarda olan İşçi Partisi hükümetini yalanlamaya, suçlu bulmaya ve krizin İngiltere'ye sıçramasından sorumlu tutmaya başladı. Gerçekte, iki tarafın birbirlerinden farkları yoktu. Bir başka Avrupa ülkesi İrlanda'da, hükümetin banka açıklarının ödenmesini garanti edecek kamusal yükümlülüklerini yerine getireceğini beyan etmesi spekülatif çılgınlık, yozlaşmış siyasi yapı bozulmaları nedeniyle bir felakete dönüştü (Krugman, 2010). Bu durum nedeniyle uluslararası piyasalarda İrlanda'nın kredi notları hızla düştü. İrlanda Merkez Bankası özel bankalarda ki kayıpların devam etmesi üzerine, bankaların iflasını önlemek için müdahale etmiştir.

Küresel bankacılık sisteminin 2008 yılında donması ve bunun Avrupa ekonomisinin daralmasına yol açması sonucu devletler borçlanarak bankalarını kefaletle kurtarma yoluna gitmiştir. Avrupa'nın en büyük bankalarından biri olan Fransız bankası BNP Paribas karmaşık yatırımlara yaptığg fon desteklerini askıya almıştır. Banka yaptığı açıklamada ; “Amerika Birleşik Devletleri'nde nakit ihtiyacının karşılanamaz hale gelmesi sebebiyle, birtakım yatırımların kalite ve kredi değeri açısından değerlendirilmesinin imkânsız hale geldiğini” belirtmiştir (Euronews, 2017).

Yunanistan ise krizden en çok etkilenen ülke olmuştur. Euro alanına girişi ve aşırı kamu harcamaları ve küresel finansal krizi nedeniyle 2009 sonunda hem iç hem de diş faktörlerin etkisi ile 1974'ten sonraki en büyük ekonomik krizini yaşamıştır. Türkiye için 2008 krizinin doğuşundan daha çok Avrupa'ya yayılması önemlidir. Türkiye ekonomisi Avrupa ekonomisi ile daha iç içe olduğu için, krizin Avrupa ayağı Türkiye üzerinde daha etkili olmuştur.

\section{2008 Küresel Finansal Krizinin Türkiye Ekonomisine Etkileri}

2007 y1lında ABD'de mortgage kredileri ile başlayan ve sonrasında bütün dünyayı etkileyen bu krizden Türkiye de çeşitli sebeplerle etkilenmiştir. Bunlardan birincisi, kredi anlamındadır. 2001 krizi sonrasında bankacılık anlamında yapısal anlamda bir bozukluk görünmese de sendikasyon kredileri ve döviz cinsinden borçlanmada birtakım sıkıntıları oluşturmuştur. İkinci olarak portföy yatırımı anlamında olup; hedge fonlar ve özel yatırım fonlarından gelen finansmanın azalacak olması döviz likiditesi anlamında sorunlara yol açmıştır. Böyle olunca Türk lirasında değer kayıpları görülmüştür. Üçüncü olarak, dış ticaret anlamında sıkıntılar ortaya çıkmıştır. Tüm dünyada ortaya çıkan büyüme hızı tahminleri aşağı yönde olunca, ülkelerin resesyona girecek olması ile birlikte küresel ticaret hacminde daralma meydana gelmiştir. Bu durumda Türkiye'nin ihracat hacmi de olumsuz etkilenmiştir. Son olarak dördüncüsü ise, artan risk algısının tüketicinin davranışlarına etkisi olup, özel yatırım harcamalarında düşüş meydana gelmiştir (Özdemir, 2014: 63-64).

Türkiye 1990, 2001 ve 2008 yıllarında küresel krizin etkilerini yaşamıştır. Özellikle 2007-2008 yıllarında yaşanan uluslararası finansal kriz Türkiye'nin ekonomisini zorladı. Fakat Türkiye karşılaşılan finansal krizlere yönelik toparlanmayı sağlayacak güçlü politikalar geliştirmiştir. A. Gallo'nun çalışmasında küresel ekonomik krizden etkilenmeleri anlamında Türkiye ve Brezilya karşılaştırılmıştır. İki ülkenin de ekonomik krizden etkilenmesine rağmen Brezilya'da işsizlik oranının çok düşük olmasından dolayı daha kolay toparlandığı ve Türkiye'de işsizlik oranı fazla olduğu için daha çok zorlandığı ifade edilmektedir (Yendi vd., 2012).

Küresel krizin olumsuz etkilerinin yanı sıra olumlu etkilerinden de söz etmek mümkündür. Türkiye'de küresel krizin olumlu etkisi, Avrupa birliği ilerleme raporunda belirtilmiştir (Avrupa Komisyonu, 2011). Raporda, Türkiye'nin kriz süresince başarılı bir para ve maliye politikası bileşimini yönettiğine dair ifadeler yer almaktadır. Ayrıca, Türkiye küresel krizden olumsuz etkilenmiş olmasına rağmen, önceki dönemlerde gerçekleştirilen denetleyici ve düzenleyici reformlar sayesinde güçlü büyüme performansını tekrardan yakalamasına değinilmiştir. Mali şeffaflık konusunda daha fazla ilerleme sağlanması, para ve maliye politikası sürece göre düzenlenmesi, enflasyon hedeflemesi ve mali istikrarın korunması konusunda tavsiyeleri bulunmaktadır.

Gelişmekte olan bir ekonomi olan Türk ekonomisinin 2001'de yaşadığı kriz neticesinde bankacılık kesiminde yaşanan yapısal dönüşümden dolayı küresel krizin Türk finans sektörüne etkisi diğer ülkelere göre daha sınırlı kalmıştır diyebiliriz. Türkiye'nin bu krizden etkilenme düzeyinin diğer ülkelere göre daha düşük olmasının iki nedeni bulunmaktadır. Bankaların yüklü miktarda dış piyasadan tahvil almaması ve yapısal olarak 2002 yılından itibaren gerçekleşen reformlar ile birlikte; kredi/sermaye oranı zorunluluğunun uygulanması ve bu oranın belirli bir düzeyde tutulmasıdır (Özdemir, 2014: 65). 2001 krizine göre bu krizde diğer ülkelere kıyasla Türkiye'de daha az kırılganlık yaşanmış olsa da, işsizlik hızlı yükseliş göstermiş, ülke ciddi anlamda gelir ve refah kaybına uğramıştır (Kibritçioğlu, 2010: 13).

Dünyada meydana gelen bu krizin gittikçe yayılarak kendisini göstermeye başladığı dönemde, Türkiye'nin ekonomik verilerine de bu krizden etkilenişi anlamında bakılması gerekmektedir. Türkiye'nin başlıca makroekonomik değişkenlerine ait, 2006-2016 yılları arasındaki veriler Tablo 2'de yer almaktadır. Tablo 2'ye detaylı olarak bakıldığında, krizin derinleştiği yıllarda büyüme, enflasyon ve işsizlik başta olmak üzere, verilerdeki olumsuzluklar dikkat çekmektedir. 
Tablo 2. Türkiye'nin Kriz Dönemi Makroekonomik Göstergeleri

\begin{tabular}{|c|c|c|c|c|c|c|c|}
\hline Yillar & $\begin{array}{c}\text { GSYH } \\
\text { (Milyar USD) }\end{array}$ & $\begin{array}{l}\text { Kişi Baş1 Gelir } \\
\text { (USD) }\end{array}$ & $\begin{array}{c}\text { Büyüme } \\
(\%)\end{array}$ & $\begin{array}{c}\text { Enflasyon } \\
(\%)\end{array}$ & $\begin{array}{l}\text { İsssizlik } \\
(\%)\end{array}$ & $\begin{array}{c}\text { Bütçe Dengesi } \\
(\%)\end{array}$ & $\begin{array}{c}\text { Cari Dengesi } \\
(\%)\end{array}$ \\
\hline 2006 & 526 & 7.597 & 6,9 & 9,6 & 9,5 & $-0,5$ & $-6,1$ \\
\hline 2007 & 649 & 9.247 & 4,7 & 8,4 & 9,9 & $-1,6$ & $-5,9$ \\
\hline 2008 & 742 & 10.444 & 0,7 & 10,1 & 12,7 & $-1,8$ & $-5,7$ \\
\hline 2009 & 617 & 8.561 & $-4,8$ & 6,8 & 12,6 & $-5,5$ & $-2,2$ \\
\hline 2010 & 732 & 10.079 & 9,2 & 6,4 & 10,6 & $-3,6$ & $-6,2$ \\
\hline 2011 & 774 & 10.444 & 8,8 & 10,5 & 9,0 & $-1,3$ & $-9,7$ \\
\hline 2012 & 786 & 10.497 & 2,2 & 6,2 & 9,3 & $-2,2$ & $-6,1$ \\
\hline 2013 & 823 & 10.822 & 4,2 & 7,4 & 9,6 & $-1,2$ & $-7,4$ \\
\hline 2014 & 800 & 10.404 & 2,9 & 8,2 & 10,9 & $-1,3$ & $-5,8$ \\
\hline 2015 & 856 & 10.877 & 6,1 & 8,8 & 10,8 & $-1,0$ & $-4,5$ \\
\hline 2016 & 852 & 10.800 & 1,8 & 8,5 & 12,1 & $-1,1$ & $-4,0$ \\
\hline
\end{tabular}

Kaynak: Eğilmez (2017)

Bu çalışmada, Tablo2'de yer alan göstergelerden Büyüme ve Üretim, İşsizlik Oranı ve Enflasyon Oranı incelenecek ve konu hakkında daha detaylı bilgilendirmeler yapılacaktır.

\subsection{Büyüme ve Üretim}

Büyüme anlamında sektör bazında bakıldığı zaman, ihracatta meydana gelen düşme ile birlikte sanayi, inşaat, ticaret ve hizmet sektörlerinde daralmalar meydana gelmiştir. Şöyle ki sanayi ve hizmet sektörüne bakıldığ 1 zaman; 2006 yılında $\% 8,3$ olan büyüme hızı 2007 yılında $\% 5,8$ 'e, 2008 yılında ise $\% 1,1$ 'e düşmüştür. İmalat sanayiinde üretim artış hızı ise 2006 y1lında \%8,4 olmuşken, 2007 y1lında \%5,6'ya, 2008 yılında $\% 0,8^{\prime}$ e düşmüştür. Hizmet sektörü açısından ise; 2006 yılında $\% 7,2$ oranında büyürken, 2007 yılında \%6'ya, 2008 yılında ise \%0,4'e düşmüştür (Yıldırım, 2010: 51). Buradan ortaya çıkan ise hem üretim sektörü anlamında hem de hizmet sektörü anlamında krizin olduğu yıllarda sektörel bazda büyümenin düşmesi ile daralmalar meydana gelmiş̧ir. $\mathrm{Bu}$ daralmalar da krizin bașta $\mathrm{ABD}$ olmak üzere bütün Avrupa ülkelerini etkilemesinden dolayı gerçekleşmektedir.

Şekil 1. Y1llar İtibariyle Büyüme Oranları (2002-2016)

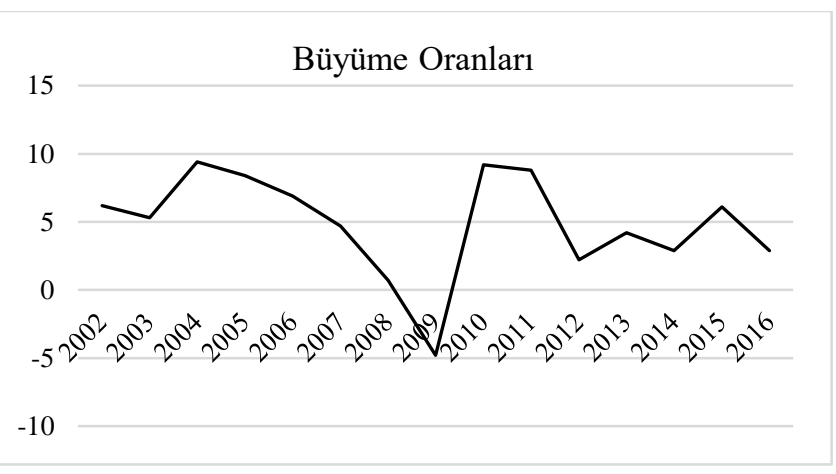

Kaynak: TÜİK (2017)

Küresel kriz sonucunda Şekil 1'den de görüldüğ̈̈ üzere 2008 ve 2009 y1llarında Türkiye'de büyüme göstergesinde önemli düşüşler yaşandığı söylenebilir. 2006 yılında \%6,9; 2007 yılında $\% 4,7$ büyüyen Türkiye ekonomisi krizin yaşanmasıyla birlikte 2008 yılında $\% 0,7$ oranında gerçekleşmiştir. Kriz etkilerinin tamamen ortaya çıktığı yıl olan 2009 'da ise Türkiye ekonomisi \% 4,8 oranında küçülmüştür. 2010 yılı ile birlikte kriz sonrasında hızlı bir toparlanma yaşanmış ve büyüme oranı $\% 9,2$ olarak gerçekleşmiştir.

Şekil 2. Sanayi Üretim Endeksi-Genel (Aylık)

\section{Sanayi Üretim Endeksi}

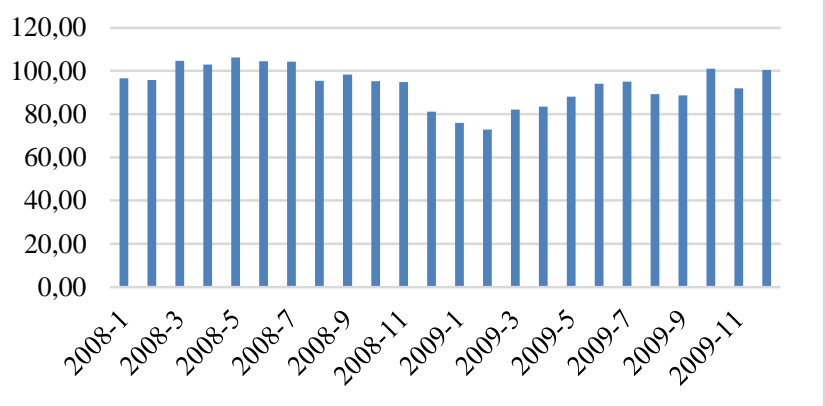

Kaynak: TÜİK (2017)

Ülkelerin GSYH'lerinin en önemli belirleyicisi olan sanayi üretim endeksine tabloda bakıldığında, Türkiye'de krizle birlikte ciddi düşüşler yaşanmış olduğu görülür. Bu konuda ciddi düşüşlerin yaşanması küçülmenin itici noktası olmuștur. Sanayi üretim endeksi verileri Temmuz 2008'de 104,3'tür. Fakat sonraki süreçte düşüş başlamış ve etkilerin en şiddetli hissedildiği 2009 yılının Şubat ayına bakıldığında 72,9'a kadar düştüğü görülmektedir. Yine büyüme verilerinde gözlemlendiği gibi, 2009'un sonlarına doğru toparlanma sürecine girilmiş ve yükseliş başlamıştır. Şöyle ki, Aralık 2009'da 100,5 olarak tekrardan eski düzeyine gelmiştir.

\section{2. İşsizlik}

Krizin Avrupa ayağında meydana gelen işten çıkarmalar olduğu gibi Türkiye'de de göstergeler anlamında bakıldığında işsiz sayısında artış olduğu ve işten çıkarmaların gerçekleştiği görülmektedir. $\mathrm{Bu}$ artışta süregelen işsizlik sorunu üzerine birde dünyada meydana gelen küresel krizin etkisi yüksektir. Bu bağlamda aşağıda krizin öncesi ve sonrası da dâhil olmak üzere, kriz ile birlikte işsiz sayısı ve işsizlik oranı yer almaktadır. 
Şekil 3. 2000-2016 Yılları Arasındaki İşsiz Sayısı ve Oranı

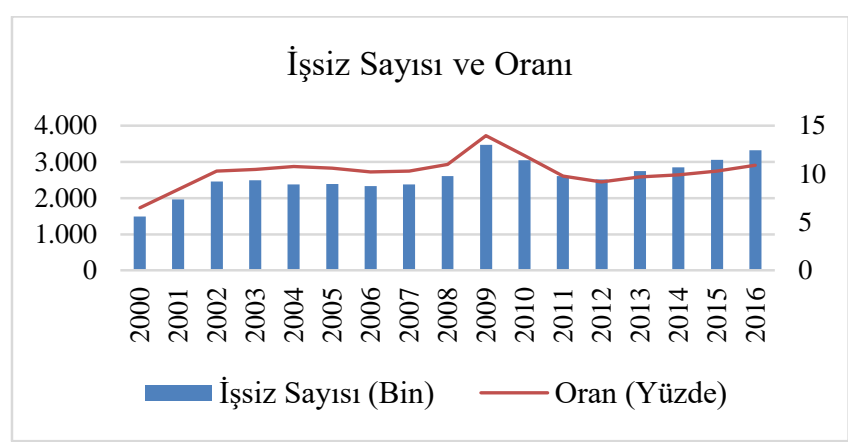

Kaynak: TÜİK (2017)

Şekil 3'e göre, 2000 yılından itibaren artan işsizlik oranı 2002 ile 2008 yılları arasında aynı oranda ilerlerken; küresel krizin etkisi ile birlikte 2008 ile 2009 yılı arasından birden bire tırmanışa geçmiştir. 2009 sonraki süreçte işsizlik anlamında toparlanma meydana gelmiştir. İçsel anlamda tepkiyi veren ekonomik yap1 sonraki süreçte toparlanma düzeyinde devam etmiştir. En yüksek oran \%14 ile 2009 yılı olmaktadır. Ayrıca işsiz sayısı anlamında bakıldığında, 2008 y1lında 2.611 milyon olarak bulunurken, 2009 y1lında krizin etkisi ile birlikte 3.471 milyon seviyesine çıkmıştır. Sonraki y1llarda düşüş olmuştur fakat tekrardan günümüze doğru artışına devam etmesinde iyi bir istihdam programı ve düzenlemesi getirilerek bu sorunun çözülmesi gerekmektedir. Her ne kadar krizde tavan olarak en yüksek düzeyde olduğu görülürken, kriz sonrası süreçte de konu hakkında önlemler alınması gerekmektedir.

Kriz döneminde işgücüne katılım oranlarına bakıldığ zaman, 2007 yılında \%44,3 iken, 2008 yılında \%44,9 ve 2009 yılında ise \%45,7 olarak artış seyrinde olduğu görünmektedir. Yine aynı yılları istihdam oranı bazında değerlendirdiğimizde, 2007 yılında \%40,3 iken, 2008 yılında \%40,4 ve 2009 yılında \%39,8 olmuştur. Ayrıca mevsim ve takvim etkilerinden arındırılmış istihdam oranına bakıldığında, Kasım 2008'de \%40,2 iken, 2009 Nisanda \%38,9'a kadar azalmıştır. Sonraki süreçte tekrardan \%40'larda devam etmiştir. İşgücüne katılma oranında ise 2009 yllında \%45'ler seviyesinde devam etmiş ve herhangi bir düşüş görülmemiştir (Şekil 3).

Yukarıda tabloda görüldüğü üzere işsizlik yükselmiş iken diğer verilere bakıldığı zaman gerek istihdam ve gerekse işgücü anlamında çok fazla negatif düşüş görülmemektedir. Avrupa ve ABD'de işten çıkarılmalar yaşanmış olsa da Türkiye'de genel anlamda etkisi 2001 krizi gibi olmamış ve hiçbir banka iflası gerçekleşmemiştir. Küçük işletmeler ve esnaflar açısından durum daha derin geçmiş olsa da yapısal anlamda daha sağlam bir duruş sergilenmiştir.

\subsection{Enflasyon}

Krizin hemen öncesi dönem ve krizle birlikte olan süreçte emtia ve petrol fiyatlarının yüksek olması, dış ticaret dengesini olumsuz etkilemiş ve Türkiye'nin enflasyon problemi yaşamasına sebep olmuştur. İşsizlik problemi ile birlikte ortaya çıkan darboğaz durum, ülkenin ekonomisindeki kısır döngüyü gerçekleştirerek kriz döneminde enflasyonun yükselişi de gerçekleşmiştir. Daha sonraki süreçte petrol fiyatlarının normale dönmesi üzerine yükseliş trendinde olan enflasyonu tekrardan aşağı yönlü olmasını sağlamıştır. Şöyle ki enflasyon 2007 yılında \%8,39 iken, 2008 y1lında küresel kriz ile birlikte $\% 10,06$ olurken, 2009 yilında \%6,53 ve 2010 yilında \%6,40 seviyelerine düşmüştür. Olumsuzluk kısa sürede atlatılarak toparlanma sürecini ortaya koymuştur. Yukarıda yıllık olarak değindiğimiz enflasyon oranlarına kriz zamanındaki süreci ve seyri ile ilgili şekil ifade edilmektedir.

Şekil 4. Tüketici Fiyat Endeks Rakamları (2008-2009)

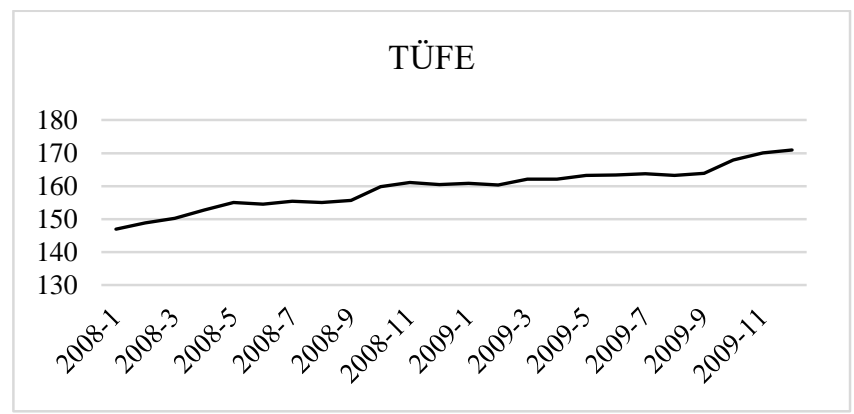

Kaynak: TÜİK (2017)

Şekil 4'te, 2008 ve 2009'daki ay bazında bakıldığında 2008'in Eylül ayından itibaren yükselmeye başlayan enflasyon 2009 yılı Aralık ayına kadar bu yükseliş trendini devam ettirmiştir. Dünyada meydana gelen kriz başta Avrupa olmak üzere bütün ülkeleri etkilediği için, Türkiye ekonomisinin önemli bir sorunu olan enflasyon da yükselmeye başlamıştır. Aşağıdaki şekilde enflasyon yıllık olarak incelenmiş olup, kriz süreci boyunca yükselişi ve sonraki süreçteki dalgalı seyri hakkında bilgileri içermektedir.

Şekil 5. Enflasyon Y1llık Değişim (2004-2016)

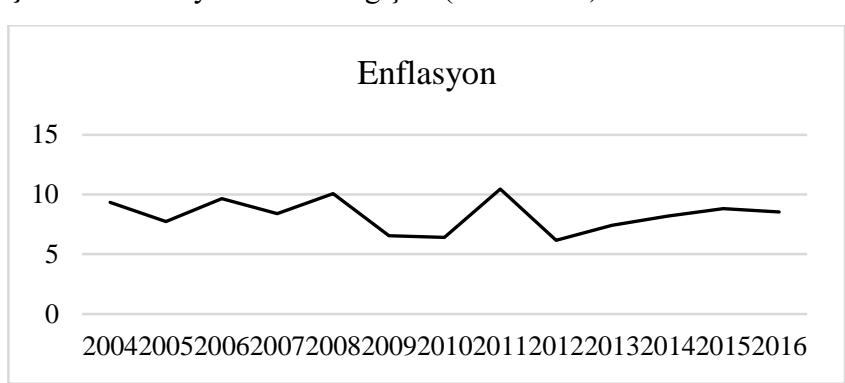

Kaynak: TÜİK (2017)

Krizin başladığı 2008 yılının son çeyreğiyle birlikte toplam talepte ciddi azalma olması ve petrol fiyatlarında düşüş yaşanması global bir enflasyon azalış trendi yaratmıştır. Ülkemizde de bu global sürecin yansımaları, enflasyon kriterinde gözlenmiştir. Ülkemizde ekonomi faaliyetlerinin durgunlaşmasında, her ne kadar yukarıda ifade edildiği gibi sağlam bir finans yapısı olsa da, dış ticarette ülke durumlarından çok hassas biçimde etkilenebilecek ürünlerin ticaretinin yapılması, yapılan üretimde kullanılan kredinin yabancı menşeli olabilmesi etkili olmuştur. Ayrıca, iktisadi faaliyetteki daralmayı derinleştiren bir diğer unsur da kriz dönemine yüksek kapasite düzeyiyle girilmiş olmasıdır. Bu dönemde yaşanan ciddi talep azalması ile Türkiye kendisini krizin içerisinde bulmuştur.

Şekil 5'te de görüldüğü gibi 2008 yılında enflasyon artmış ve sonrasındaki yıllarda düşüş eğiliminde olmuştur. Aylık olarak bakıldığında en yüksek artış 2008 yılı Ekim ayında \%2,60’lık bir artış gerçekleşmiştir. Ayrıca bir önceki yılın aynı ayına göre değişim sürecine bakıldığında, 2008 yılı 
temmuz ayında \%12,06 ile Ağustos, Eylül, Ekimde ise yine $\% 11$ seviyelerinde olarak y1lsonu enflasyonu \%10,06 olmuştur. Türkiye'de enflasyon 2009 yılının Mart ayında $\% 7,89$ oranında olup sonraki süreçte düşüş seyrinde iken, 2009 yılının son üç aylık döneminde ise artış trendi yaşanmıştır. Bunun nedeni, talep artışları yaşanmasıdır. Aynı zaman diliminde petrol ve diğer emtia fiyatlarındaki artış olması ve bu süreçte yapılan vergi teşviklerinin bitmesiyle artış tekrardan gözlenmeye başlamış̦tır. $\mathrm{Bu}$ doğrultuda 2009 yılının son üç aylık döneminde yıllık enflasyon Eylül ayında \%5,27 oranından, Aralık ayında $\% 6,53$ düzeyine yükselmiştir. Enflasyon oranında kriz döneminde yukarıda ifade edildiği gibi bir yükselme görülmektedir. Kaydedilen bu artış, sürdürülen para politikasının etki alanı dışında kalan unsurlar ile dünyada meydana gelen geçici unsurlardan kaynaklanmaktadır.

\section{Sonuç ve Değerlendirme}

2008 yılında ABD'de mortgage krizi olarak başlayan ve ilerleyen süreçle birlikte tüm dünyaya yayılan bir likidite krizi halini alan süreç tüm dünya ekonomilerini derinden sarsmıştır. ABD ekonomisinin içerisine düştüğü darboğaz, ABD'nin her ülkenin müşterisi olma konumu nedeniyle tüm ülkelerin ekonomilerini daraltmıştır.

ABD'nin Bear Stearns isminde ki bankası, Mart ayında şirketin tamamını 236 milyon dolar olarak belirlenen değerinden çok daha düşük fiyata, hisse başı 2 dolar fiyatla JP Morgan'a sattı. Oysaki bu banka ABD'nin en büyük bankası olarak biliniyordu. Şirketin Ocak 2007'deki piyasa değeri 20 milyar dolar olarak belirlenmiști. Bear Stearns'ten iki günde 17 milyar dolar para çekilmesinin üzerine iflas edeceği anlaşılınca Fed, batışın tüm sisteme yayılmasını önlemek için ellerinde satılma ya da iflas masasına gitme seçeneklerini kaldı. Fed, şirketin JP Morgan'a devri gerçekleşmezse Bear Stearns'e yardım etmeyeceğini ifade etti. Bear Stearns yetkilileri de, 84 dolar olarak açıkladıkları hisse başına defter değerine rağmen hisseleri 2 dolara karşılığında JP Morgan'a devretmeye mecbur kaldı.

Çalışmada belirtildiği üzere Türkiye, 2008 krizinde, krizin as1 nedeni olan finansal sorunlarla, 2001 krizi sonras1 yapılanması nedeniyle karşılaşmamıştır. Ancak tüm dünyanın yaşadığı krizin, uluslararası kredileri baltalaması sonucu kredi maliyetlerinde yaşanan artışlar, tüm dünyada küresel talep daralmasının yaşanması gibi nedenler neticesinde reel sektörde ciddi kayıplar yaşamıştır. Küresel ekonomide yaşanan daralma nedeniyle 2008 mali krizi Türkiye'ye dış ticaret bazlı olumsuz sonuçlar yaratmıştır. Türkiye'nin aktif dış ticaret alanı olan Avro bölgesinin ekonomik sorunları neticesinde ihracatımız çok ciddi şekilde azalmıştır.

Küresel ekonomik kriz ile birlikte tüm sektörlere yayılan darboğaz neticesinde dünyada istihdam oranlarında ciddi düşüşler yaşanmıştır. Tüm gelişmelerin birbirinden etkilenerek büyüdüğü global dünyada Türk istihdam piyasası da olumsuz etkilenmiş ve işsizlik oranında önemli artışlar meydana gelmiştir. Tüm dünyada artan işsizlik oranı neticesinde işsizlik \%16 seviyelerine gelmiştir. Tüm makroekonomik göstergelerin birbirini etkilediği kriz sürecinde de imalat sanayi kapasite kullanımı oranında da 2008'in ikinci üç aylık döneminde daralma gözlenmiştir. Kriz süresince Dünya'da talep arttırıcı önlemler alınırken
Türkiye'de iç talep arttırıcı politikalara başvurulmada geç kalınması krizi daha da derinleştirmiştir. Bazı kontrol mekanizmaları kurulmasına rağmen toplumda ekonomiye güvensizlik durumu gelişmiştir. Türkiye'nin ağır sanayide önemli ölçüde dışa bağımlı olması neticesinde uygulanan vergi teşviklerinin diş ülkelere kayan bir durum haline gelmesine yol açmıştır.

Yaşanan krizden ülkemiz adına alınması gereken ders kontrol ve denetim mekanizmalarının arttırılması gerekliliğidir. Bu noktada 2001 krizi yapılanmasının faydası bu krizde görülmüştür. Risk algısının geliştirilmesi ile risk kültürünün oluşturulmasının çok önemli olduğu söylenebilir. Küresel kriz sürecinde hem dünya ülkeleri hem de Türkiye bir takım önlemler alma yönünde ilerlemişlerdir. Dünya ülkeleri talebi arttırmaya yönelik genişletici tedbirler almışlardır. Türkiye ise artan bütçe açığını daha da arttırmamak için iç talebi arttırmaya yönelmiş ve bu nitelikte genişletici politikalara yönelmekte gecikmiştir. Bu gecikme Türkiye'de krizin etkilerinin derinleşmesine sebep olmuştur. Gecikmeli olarak alınan tedbirler, ÖTV indirimi, işsizlerin istihdam edilmesi, işsizlere mesleki eğitim verilmesi, kredi kartlarına düzenleme getirilmesi gibi tedbirlerdir. Türkiye ekonomisinde küresel krizin ilk etkisi finansal piyasalarda görülmüştür. 2008 yılında, İMKB bileşik fiyat endeksine bakacak olursak, Ocak ayında yaklaşık 43.000, Eylül ayında 36.000 , Aralık ayına ise 27.000 'e düşmüş olduğu görülür. Küresel ekonomik kriz kendini önce borsada gösterir. Daha sonra da reel ekonomide ortaya çıkar. Türkiye ekonomisine yansımasına bakıldığında 2007 yılından başlayarak tarım, sanayi ve hizmetler sektöründe büyüme hızlarının düşmüş olduğu karşımıza çıkmaktadır. Bundan dolayı da GSMH'da (Gayri Safi Milli Hasıla) azalma meydana gelmiştir. GSYH büyüme hızı 2007 yılının sonunda \%4,7 iken 2008 yılının Ağustos ayı sonunda \%0,9'a düşmüştür. İşletmelerin talep yetersizliğine bağlı olarak kapasite kullanım oranlarında da düşüş görülmektedir.

Türkiye'de 2000'li y1llarda büyüme oranında gelişmekte olan ülkeler ortalamasının altında kalmıştır. Çünkü bu alanda Türkiye istikrarsız bir yapı sergilemiştir. 2003-2009 arasında 7 yılda kümülatif $(2002=100)$ olarak gelişmekte olan ülkelerde büyüme ortalaması yüzde 54 iken Türkiye'de bu oran yüzde 32.3 olarak tespit edilmiştir. Türkiye'de GSYİH 2008 IV. Çeyreği ile 2009 III. Çeyreği arasındaki bir yılda yüzde 8,4 oranında azalmıştır. Türkiye'de 2002'de işsizlik ortalaması yüzde 10,3 iken 2009'da Ekim ayında bu oranın değişiklik gösterdiği ve yüzde 13'e yükseldiği görülmüştür. G-20'ler içerisinde İspanya'dan sonra en yüksek işsizlik oranlarına sahip olan ikinci ülke Türkiye'dir. Türkiye'nin fiili ișsizlik oranının İspanya'dan da yüksek olduğu düşünülebilir. 2009 yılında, dünya ticaret hacmi yüzde 11,9 daralırken, Türkiye'nin dış ticaret hacminin yüzde 34,8 oranında daraldığı görülmüştür.

2008 Dünya krizi ABD’de ki mortgage krizi ile başlamış, denetleyen kuruluşların görevlerini yeterince yapmayıp açık vermeye başlamalarıyla, verilen kredilerin geri ödenememesi üzerine kriz patlayıp, dünya bankalarını ve dolayısıyla dünya genelini etkilemiştir. Türkiye'nin global cari açıklığı ise, OECD raporuna göre diğer ülkeler üzerinden en küçülen ülke olmuştur. Ülkemiz ise Yunanistan ve İspanya ile beraber en çok etkilenen ülkelerden biri olmuştur. Yunanistan ise Euro kriziyle beraber bu krizde de bayağı sarsılmıştır. İşsizlik oranı 3 ülkede de yükselmiştir. 
Global bir kriz olduğundan tüm dünya etkilenmiştir, ülkemizdeki avro ihracatı azalmış, dolayısı ile cari açık yükselmiştir. Bir de özelleştirmelerin artması işsizliğin artmasını tetiklemiştir.

\section{Kaynakça}

Akın, F., \& Ece, N. (2009). Küresel Finansal Kriz ve Bankacılık Sektörü İstihdamı Üzerindeki Etkileri. Marmara Üniversitesi III BF Dergisi, 27(2), 153168.

Aktel, M. (2003). Küreselleşme ve Türk Kamu Yönetimi. Ankara: Asil Yayın Dağıtım.

Avrupa Komisyonu (2011). Türkiye 2011 Yılı İlerleme Raporu. (Erişim: 10.12.2017), https://www.ab.gov.tr /files/AB_Iliskileri/AdaylikSureci/IlerlemeRaporlari/20 11_ilerleme_raporu_tr.pdf

Bağımsız Sosyal Bilimciler (2009). Türkiye'de ve Dünyada Ekonomik Bunalım, 2008-2009. İstanbul: Yordam Kitap.

Çetinkaya, M. (2011). Küresel Finansal Kriz: Küresel Ekonomik Kriz ve Belirleyicileri Üzerine Bir Değerlendirme. Ankara: Nobel Yayınevi.

Eğilmez, M. (2017). Son 14 Yılda Türkiye Ekonomisi. (Erişim: 10.12.2017), http://www.mahfiegilmez.com /2017/03/son-14-ylda-turkiye-ekonomisi.html

Erdönmez, P.A. (2009). Küresel Kriz ve Ülkeler Tarafindan Alınan Önlemler Kronolojisi. Bankacılar Dergisi, 68, 85-101.

Euronews (2017). 2008 Ekonomik Krizinin Etkileri Sürüyor. (Erişim: 10.12.2017), http://tr.euronews.com/2017/ 08/09/2008-ekonomik-krizinin-etkileri-suruyor

Gümüş, F.B., \& Aydemir, L. (2014). 2008 Küresel Finans Krizinin Sektörel Bazda Şirket Mali Tablolarına Etkilerinin Analizi. İşletme Bilimi Dergisi, 2(1), 37-64.

Günceler, B. (2015). Bankalarda Aktif Pasif Yönetimi Ders Notlar1.

Kibritçioğlu, A. (2010). Küresel Finansal Krizin Türkiye'ye Etkileri. MPRA Papers, WP No. 29470. (Erişim: 10.12.2017), https://mpra.ub.uni-muenchen.de/29470 /1/MPRA_paper_29470.pdf

Klimek, A. (2012). Global Foreign Direct Investment Flows and The Ekonomic Crisis. International Journal of Emerging and Transition Economies, 5(1-2), 47-56.

Krugman, P. (2010). Eating the Irish. The New York Times. (Erişim: 10.12.2017), http://www.nytimes.com/2010/ 11/26/opinion/26krugman.html

Ouerghi, F. (2013). Global Financial Crisis: Did Exchange Rate Politics Help Emerging Countries to be More Resilient?. International Journal of Economics and Financial Issues, 3(4), 949-963.

Özdemir, İ. (2014). Küresel Mortgage Krizi ve Türkiye Ekonomisine Etkileri. Yüksek Lisans Tezi. Bolu: Abant İzzet Baysal Üniversitesi.

Seyidoğlu, H. (2003). Uluslararası Mali Krizler, İmf Politikaları, Az Gelişmiş Ülkeler, Türkiye ve Dönüşüm Ekonomileri. Doğuş Üniversitesi Dergisi, 4(2), 141-156.
TÜİK (2017). Istatistik Göstergeler. (Erișim: 10.12.2017), https://biruni.tuik.gov.tr/gosterge/?locale $=$ tr

Uğur, A. (2007). Mortgage. İstanbul: Destek Yayınları.

World Bank (2009). Global Economic Prospects. Commodities at the Crossroads. Washington DC: Dünya Bankası.

Yalçinkaya, M. H., Çilbant, C., \& Yalçinkaya, N. (2012). Küreselleşme ile Yeniden Şekillenen Ulus-Devlet Anlayışı. Uluslararası Íktisadi ve İdari Incelemeler Dergisi, 4(8), 1-26.

Yendi, R., Çetin, S., \& Gallo, A. (2012). The Turkish Economy and The Global Crisis. International Business: Research, Teaching and Practice, 6(2), 45-58.

Yıldırım, S. (2010). 2008 Yılı Küresel Ekonomi Krizinin Dünya ve Türkiye Ekonomisine Etkileri. KMÜ Sosyal ve Ekonomik Araştırmalar Dergisi, 12(18), 47-55.

Yurdakul, H. (2015). 2008 Küresel Ekonomik Krizi ve Türkiye'ye Etkisi. Ekonomi-Maliye Sahipkıran Akademi Yazıları. (Erişim: 10.12.2017), http://sahipkiran.org/ 2015/01/12/kuresel-ekonomik-kriz/ 